patient undergoing duodenal biopsy who had had a Polya gastrectomy. Shiner thought that with minor modifications biopsies could be obtained from the normally sited jejunum..$^{14}$

Once the first part of the duodenum had been reached, a rubber balloon attached to the distal end of the head piece was inflated and this, it was found, allowed the head to travel through the third and fourth parts of the duodenum and so reach the jejunum (fig 4).

Margot Shiner's biopsy tube was rather cumbersome. In Puerto Rico, where Haas had first noted the higher incidence of sprue in town dwellers as opposed to farmers whose diet contained a large proportion of bananas, Lieutenant Colonel W H Crosby of the United States army recognised the need for a more flexible instrument for obtaining jejunal biopsies for examination by the army's sprue team. Various triggering devices for initiating the action of a spring loaded knife were considered. Timers, solenoids, and magnets were rejected in favour of an air pressure mechanism, and in 1957 he and Heinz W Kugler published details of what has become known as the Crosby capsule. ${ }^{15}$
I thank Sir Christopher Booth for permission to quote from his address to the Derby Medical Society, the librarians and medical illustrators at the Derbyshire Royal Infirmary, the BMA Nuffield Library, and Margaret Barker, who translated the aphorism of Heraclitus.

1 Adams F. The extant works of Aretaeus the Cappadocian. London: London Sydenham Society, 1856:350.

2 Dowd B, Walker-Smith J. BrMed f 1974; ii:45-7.

3 Gee SJ. On the coeliac affection. St Bartholomew's Hospital Report 1888;24: 17-20.

4 Gibbons RA. The coeliac affection in children. Edinburgh Medical Journal 1889;i:321-30, 420-8.

5 Cheadle WB. Acholia. Lancet 1903;i:1497-500.

6 Herter CA. Infantilism from chronic intestinal infection: New York: Mac-

millan, 1908.
Still CF. The Lumleian lectures on coeliac disease. Lancet 1918;ii:163-6, 193-7, 227-9.

8 Haas SV. The value of the banana in the treatment of coeliac disease. Am $\mathcal{J} D$ is Child 1924;24:421-37.

9 Haas SV. Coeliac disease. NY State $f$ Med 1963 May 1:1346-50.

10 Paulley JW. Observations on the aetiology of idiopathic steatorrhoea. BrMed f 1954;ii:1318-21.

11 Kenamore B. A biopsy forceps for the flexible gastroscope. American fournal of Digestive Diseases 1940;7:539.

12 Wood IJ, Doig RK, Motteram R, Hughes A. Gastric biopsy. Lancet 1949;i: 18-21.

13 Shiner M. Duodenal biopsy. Lancet 1956;i:17-9.

14 Shiner M. Jejunal biopsy tube. Lancet 1956;i:85.

15 Crosby WH, Kugler HW. Intraluminal biopsy of the small intestine. American foumal of Digestive Diseases 1957;2:236-41.

\title{
South African gem of medical history
}

\author{
Philip Rhodes
}

Last June Dr V C Lucas reported that he had learnt about early anaesthesia and the discovery of diamonds in South Africa at the medical history museum in Johannesburg (25 June, p 1795). He found that both activities had been pioneered by William Guybon Atherstone.

I had never heard of the Adler Museum of the History of Medicine but when my wife and I were in South Africa recently we found that it was only about a mile from our hotel.

It was worth seeking out in the South African Institute for Medical Research in the grounds of the Johannesburg General Hospital because it is a gem. My experience of museums is slender, but I have seen nothing on the subject of medical history resembling the Adler Museum. General museums, such as in York

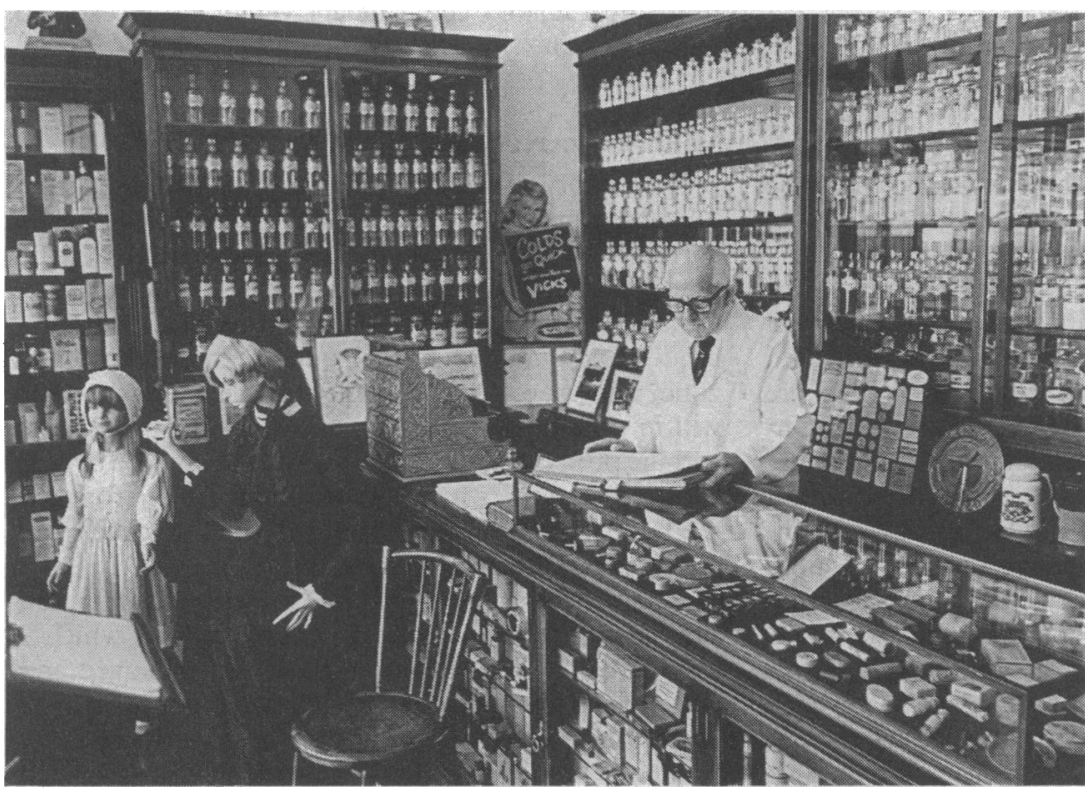

Dr Cyril Adler in his 1906 pharmacy

and in Norwich, have reconstructions from previous centuries of shops containing examples of what they purveyed, and of rooms showing all the paraphernalia with which our ancestors surrounded themselves. You feel as if you were there with them. The museums are living history, stimulating the imagination, and designed to provoke responses in the onlooker.

The Adler Museum is a work of art too. You round the corner of a house into a paved street, lit by gas lamps, with wrought iron railings and grass in front of the dentist's and the doctor's surgeries. Next door to the doctor's is a glass coach house showing off his carriage. The end of the street is mainly closed in by the chemist and druggist's (apotheker) shop. The house opposite the doctor's surgery was formerly that of the director of the South African Institute for Medical Research. There are several rooms most beautifully laid out with medical and nursing memorabilia. They are not large and overwhelming, but each is a happy and welcome surprise.

\section{Begged, borrowed, and purloined}

We walked into the house wondering what we might find. In the office was Dr Cyril Adler himself. It was embarrassing to confess that I had never heard of his museum, but he turned out to be a most welcoming and genial host.

The museum was donated to the University of Witwatersrand by its founders, the Adlers, in 1974, and at present the collection is run under the aegis of the university. Dr Adler, now the director of his own museum, with the help of his late wife, collected, begged, borrowed, bought, and perhaps purloined virtually all the items displayed. The Adlers took many years and travelled the world to get them. Like many other universities Witwatersrand can find little support, financial and otherwise, for the subject of medical history. There are no overt plans for the museum when Dr Adler dies and he is now well into his 80s. Unless the university, or the city of Johannesburg, 


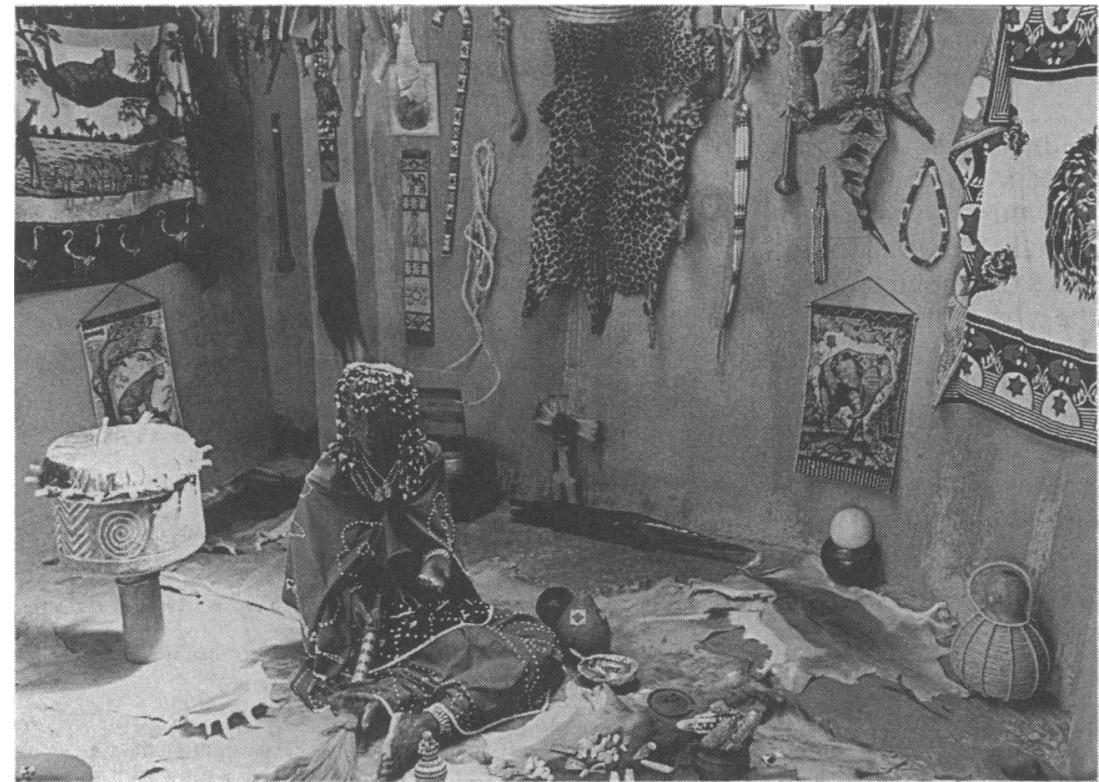

African witchdoctor with the tools of her trade

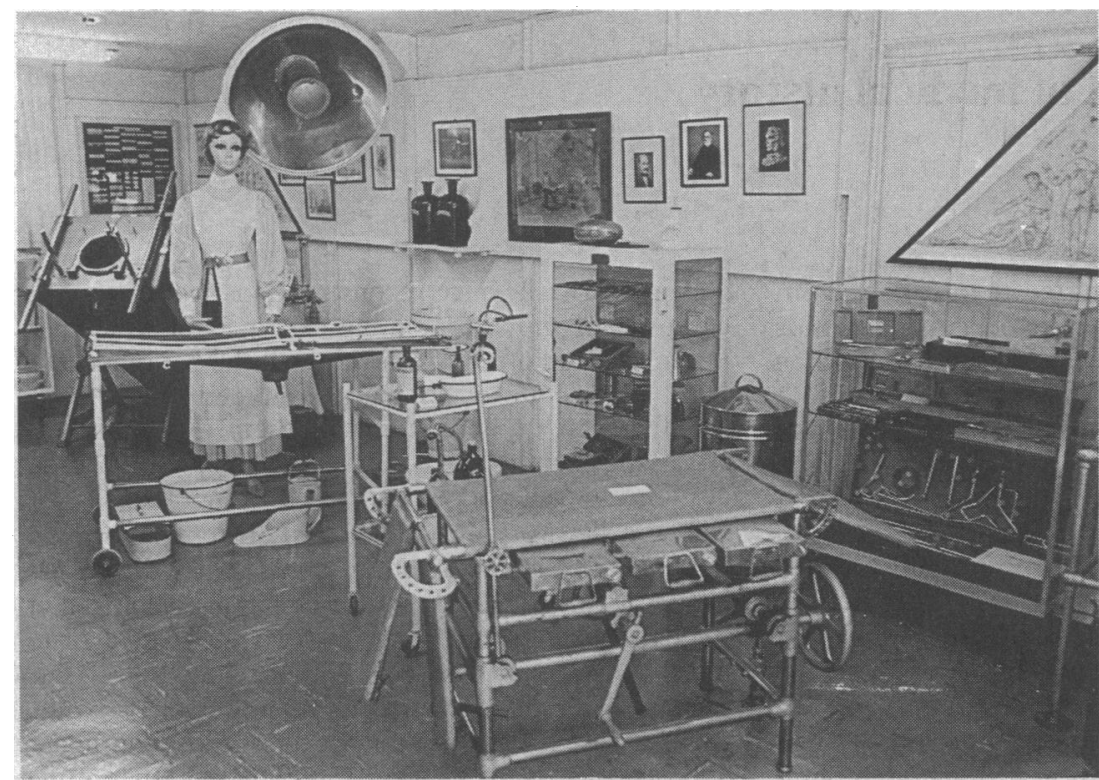

Reconstruction of a 1906 hospital operating theatre
This particular machine was used by Queen Victoria to ease her rheumatism.

Another room is set up as an operating theatre complete with a life sized effigy of a nurse presiding over the table, which to modern eyes is very crude. The anaesthetic machine and iron lung look oldfashioned now though many of us thought them the last word in modernity when they were first introduced.

\section{Whiff of herbs}

Out at the back in an outhouse is a pièce de résistance. It is the African matlala or chemist's and herbalist's shop. As the door is opened there is whiff of herbs and of pagan tribal gods. An effigy of a woman squats on the floor on a lion's skin complete with its head. She is colourfully clad and surrounded by the tools and totems of her trade. The dried plants and herbs hang round the walls, and there is a remedy for everything in the lexicon of African medicine. We were transported into a different world beyond Western understanding.

The early twentieth century chemist's shop in the street is also remarkable. It once stood in a main street of Johannesburg, but somehow Dr Adler managed to acquire it and have it transported to its present site, complete with the name board of the street. There are elegant curved windows at the entrance. Inside are a life sized chemist behind the counter and a woman and her child as customers. There is a cash register and mahogany cabinets of excellent workmanship, with their little drawers labelled and containing all the ancient remedies. In a more modern section are first prescription packets of salvarsan and of sulphanilamide. And of course there are massive jars and big flasks of coloured liquids.

Dr Adler also begged the doctor's surgery just down the street. As I walked in I recalled my own general practitioner's surgery in the 1930s. There was the roll top desk with its little drawers and shelves, the doctor's wooden armchair, the lino and threadbare rug, the chaise longue, the leather couch, the instruments of the profession in a glass fronted, glass shelved cupboard, and all completed by the lower half of the window being painted and hung with lace curtains.

So it went on, with artefacts of dentistry, ophthalmology, otolaryngology, and machines of almost forgotten purpose because they were based on such different concepts from our own. The exhibition is supplemented by a comprehensive library and an incomparable cross indexing system of biographies and medical historical articles. It seemed as if any question in medical history could be answered and researched within minutes.

or the government do something soon they will lose the jewel of scholarship which Dr Adler has burnished and polished.

Despite recovering from heart surgery nothing would do but that he should show us round his pride and joy personally. His enthusiasm and erudition were generously yet modestly displayed as he showed us and discoursed on the exhibits which pleased him most. The main room has display cabinets with all the usual medical and surgical instruments and bits of outdated equipment associated with such a collection. They are all superb examples of their kind and in mint condition. There is a fine display of dozens of richly decorated feeding cups, busts of noteworthy doctors, especially one of Maimonides, and bas-reliefs of them, too, most of these being specially commissioned. There is an electrocardiograph of 1917 and the first record made on it, printed on glass. Close by is a "Patent Magnetic Electrical Machine" for nervous diseases. With the patient holding an electrode in each hand, or with a string of people holding hands and connected to the electrodes, a handle is cranked to generate electricity which causes a mild tingling shock.

\section{Valuable corrective}

It is important that the museum is within an institute for medical research. Its scholarship can be a valuable corrective for the fashions, fads, and fallacies of the present. It will help to keep wilder flights of fancy tethered to the ground. So many theories, and techniques and lunacies built on them, have come and gone, and there are still plenty of them today, which will in turn be relegated to limbo. To have the dross and the pure metal displayed imaginatively side by side is an education, which should not be lost from the medical curriculum. At least it may help to curb some of the more fantastic enthusiasms.

Johannesburg is an unhappy city with racial tension simmering everywhere. It is not a place to which I would wish to return, yet to have met this aged and wise scholar and seen the museum and library which he has created banished for an hour or two the sad city from my thoughts and left at least one untarnished memory. 